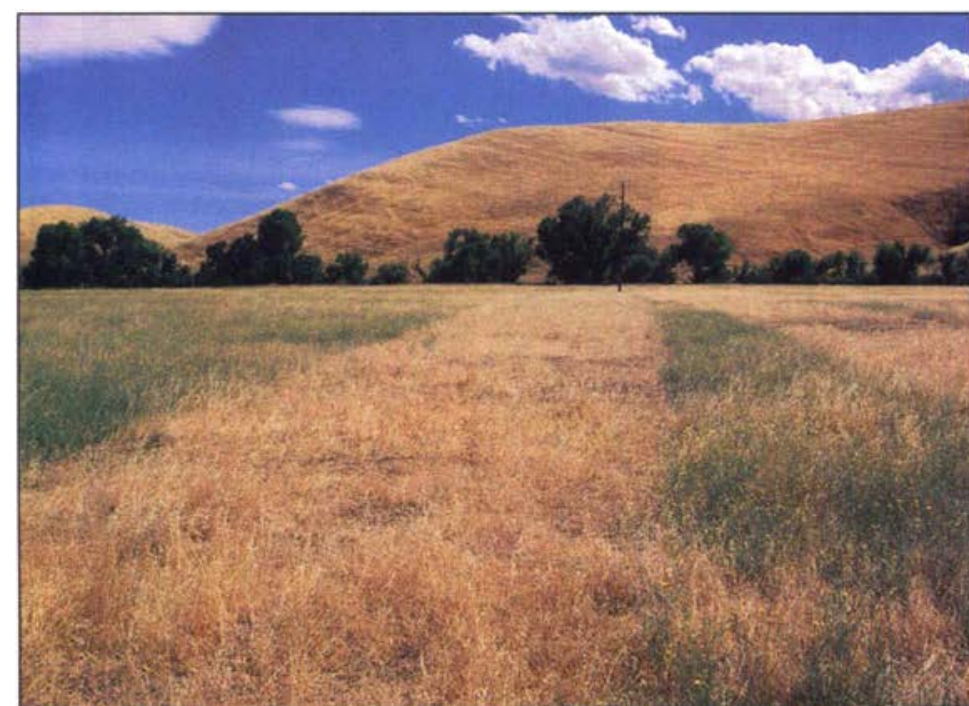

Application skip following ground application of clopyralid in yellow starthistle infested field.

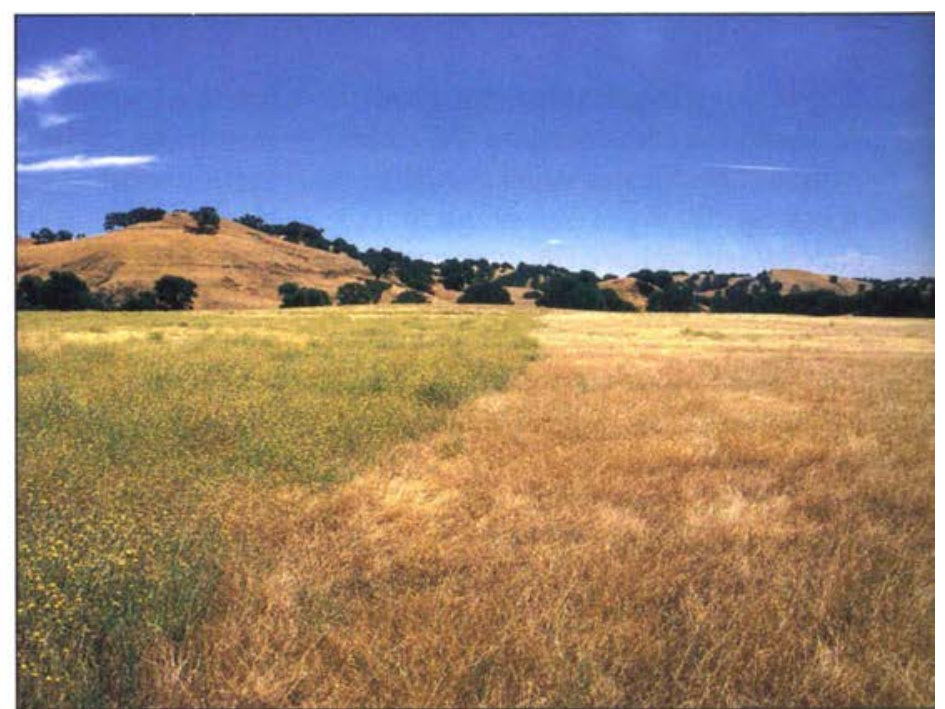

Aerial treatment of clopyralid on right and untreated plot on left.

\title{
New growth regulator herbicide provides excellent control of yellow starthistle
}

Joseph M. DiTomaso $\square$ Guy B. Kyser $\square$ Steve B. Orloff $\square$ Stephen F. Enloe $\square$ Glenn A. Nader

Yellow starthistle is the most widespread invasive weed in California. An exotic that invaded California in the Gold Rush days, starthistle was once a minor annoyance but is now out of control. One reason is that few herbicides are registered for use on California rangelands, pastures and wildlands. Of the registered herbicides, the majority are effective only when applied to the foliage of target plants; season-long control of yellow starthistle is not provided because seedlings that emerge after application of the herbicide escape injury. In a comparison of herbicides, the newly registered herbicide clopyralid provided excellent control at low use rates and worked equally well whether applied to leaves or to soil to control germinating seedlings. In soil, it showed residual activity throughout the season. Complete yellow starthistle control was achieved with applications made from December through April, but treatments in February maximized desirable forage production, particularly grasses. Late-season applications of glyphosate and clopyralid were effective for control of starthistle plants in late rosette and bolting stages.

Yellow starthistle has become common in open areas on roadsides, rangeland, wildlands, hay fields, pastures and waste areas. It can form dense infestations that rapidly deplete soil moisture, thus preventing the establishment of other species. Effective long-term management of yellow starthistle will likely be achieved with the use of an integrated approach. This could include the use of biological control agents, mowing, prescribed burning, properly timed grazing, reseeding programs and the judicious use of herbicides.

Yellow starthistle can be controlled with a number of nonselective preemergence herbicides, including simazine, diuron, atrazine, sulfometuronmethyl, chlorsulfuron, bromacil, tebuthiuron, oxyfluorfen and prometone. All these compounds are registered for use on rights-of-way or industrial sites, but few can be used in rangeland, pastures or wildlands. In rangeland, no preemergence herbicide provides selective control of yellow starthistle without injuring desirable grasses. Chlorsulfuron is the only selective preemergence herbicide currently available that effectively controls yellow starthistle in noncrop areas, but it does not have postemergence activity on yellow starthistle and must be used in combination with 2,4-D, dicamba or triclopyr to provide some level of control.

A major problem with postemergence herbicides to control yellow starthistle (Centaurea solstitialis L.) has been the weed's ability to germinate continuously throughout winter, spring and into summer whenever moisture is available. As a result, repeated applications of broadleaf selective, postemergence herbicides such as 2,4-D, dicamba or triclopyr are required. One late application at the end of the rainy season is not sufficient be- 
cause many plants are too large and are not completely controlled.

Clopyralid (Transline) is a growthregulator herbicide that arrests development of the growing points of the plants. It was recently registered for use in noncrop areas of California, including pastures, rangeland and wildlands. It is not expected to impact the biological control agents and has been demonstrated to be very safe on grasses but effective for the control of many members of the sunflower family (Asteraceae), as well as legumes (Fabaceae), nightshades (Solanaceae), and some species in the knotweed (Polygonaceae) and carrot (Apiaceae) families. In contrast, many other broadleaf species, including those in the mustard family (Brassicaceae) and filarees (Erodium spp.), are tolerant to the herbicide. Unlike other postemergence compounds, clopyralid also has excellent preemergence activity and is effective at very low use rates. In these experiments, we compared rates and timing of several noncrop herbicides for yellow starthistle control, from before emergence through reproductive maturity.

\section{Starthistle seedling control}

We established field trials in Davis in March 1996 to compare several postemergence herbicides and the preemergence herbicide chlorsulfuron on yellow starthistle seedlings. Each plot was 5 feet by 10 feet and all treatments were applied using a $\mathrm{CO}_{2}$-pressurized backpack sprayer delivering 40 gallons per acre of spray mixture at a pressure of 20 pounds per square inch (psi). A similar experiment was also established in Davis in November 1996 to determine the most effective application timing (November to April) for control of yellow starthistle seedlings and rosettes using clopyralid, 2,4-D, triclopyr, and combinations of chlorsulfuron and 2,4-D or triclopyr. In this experiment, plots were 8 feet by 15 feet and treatments were applied using a $\mathrm{CO}_{2}$-pressurized backpack sprayer delivering 20 gallons per acre at 30 psi. All treatments in both experiments were replicated four times. Visual evaluations were used to assess percent control. Because clopyralid acts slowly on starthistle seedlings, evaluations were made at least 2 months following treatment.

Chlorsulfuron typically provides excellent postemergence and preemergence control of many weed species. However, in our first 1996 trial it gave little postemergence control of yellow starthistle, even at the highest rate, 2 ounces active ingredient per acre $(\mathrm{oz}$ ai/A) with or without a surfactant (table 1). When chlorsulfuron was combined with 2,4-D or triclopyr, yellow starthistle control improved to as much as $91 \%$. Because of the high seed production in yellow starthistle infestations, this level of control is not considered acceptable for long-term starthistle management. Application of 2,4-D in March followed by a second treatment in May controlled $96 \%$ of the yellow starthistle. Although not statistically significant, $2,4-\mathrm{D}$ was consistently more effective than triclopyr. Clopyralid at the lowest rate tested in this experiment ( $1 \mathrm{oz}$ acid equivalent/ acre, $1 / 6$ pint product/acre) was not statistically different from repeated applications of triclopyr or 2,4-D, but

TABLE 1. Chemical control of yellow starthistle seedlings in Central Valley grasslands (Davis) in March 1996

\begin{tabular}{|c|c|c|c|c|}
\hline Herbicide & $\begin{array}{c}\text { No. of } \\
\text { applications }\end{array}$ & $\begin{array}{c}\text { Rate } \\
\text { per acre }\end{array}$ & Surfactant & Control \\
\hline & & & & $\%$ \\
\hline \multirow[t]{5}{*}{ Clopyralid } & 1 & $1.0 \mathrm{oz} \mathrm{ae}$ & - & $100 \mathrm{a}^{*}$ \\
\hline & 1 & $2.0 \mathrm{oz}$ ae & - & $95 \mathrm{a}$ \\
\hline & 1 & $4.0 \mathrm{oz}$ ae & - & $100 \mathrm{a}$ \\
\hline & 1 & $6.0 \mathrm{oz}$ ae & - & $100 \mathrm{a}$ \\
\hline & 1 & $8.0 \mathrm{oz}$ ae & - & $100 \mathrm{a}$ \\
\hline \multirow[t]{6}{*}{ Chlorsulfuron } & 1 & $0.5 \mathrm{oz}$ ai & - & $3 \mathrm{~h}$ \\
\hline & 1 & $1.0 \mathrm{oz}$ ai & - & $18 \mathrm{fgh}$ \\
\hline & 1 & $2.0 \mathrm{oz}$ ai & - & $18 \mathrm{fgh}$ \\
\hline & 1 & $0.5 \mathrm{oz}$ ai & $0.1 \%$ Sylgard & $15 \mathrm{fgh}$ \\
\hline & 1 & $1.0 \mathrm{oz}$ ai & $0.1 \%$ Sylgard & $29 f$ \\
\hline & 1 & $2.0 \mathrm{oz}$ ai & $0.1 \%$ Sylgard & $33 \mathrm{f}$ \\
\hline \multirow[t]{3}{*}{$\begin{array}{l}\text { Chlorsulfuron } \\
+2,4 \text {-D }\end{array}$} & 1 & $\begin{aligned} & 0.5 \mathrm{oz} \text { ai } \\
+ & 1 \mathrm{lb} \text { ae }\end{aligned}$ & $0.1 \%$ Sylgard & $83 \mathrm{abcd}$ \\
\hline & 1 & $\begin{aligned} & 1.0 \mathrm{oz} \text { ai } \\
+ & 1 \mathrm{lb} \text { ae }\end{aligned}$ & $0.1 \%$ Sylgard & 63 de \\
\hline & 1 & $\begin{array}{l}2.0 \mathrm{oz} \text { ai } \\
+1 \mathrm{lb} \text { ae }\end{array}$ & $0.1 \%$ Sylgard & $91 \mathrm{ab}$ \\
\hline \multirow[t]{3}{*}{$\begin{array}{l}\text { Chlorsulfuron } \\
+ \text { triclopyr }\end{array}$} & 1 & $\begin{array}{r}0.5 \mathrm{oz} \text { ai } \\
+0.5 \mathrm{lb} \text { ae }\end{array}$ & $0.1 \%$ Sylgard & $25 \mathrm{fg}$ \\
\hline & 1 & $\begin{array}{r}1.0 \mathrm{oz} \text { ai } \\
+0.5 \mathrm{lb} \mathrm{ae}\end{array}$ & $0.1 \%$ Sylgard & $86 a b c$ \\
\hline & 1 & $\begin{array}{r}2.0 \mathrm{oz} \text { ai } \\
+0.5 \mathrm{lb} \text { ae }\end{array}$ & $0.1 \%$ Sylgard & 69 cde \\
\hline \multirow[t]{2}{*}{ 2,4-D } & 1 & $1 \mathrm{lb}$ ae & $0.1 \%$ Sylgard & 74 bcde \\
\hline & 2 & $1 \mathrm{lb}$ ae & $0.1 \%$ Sylgard & 96 a \\
\hline \multirow[t]{2}{*}{ Triclopyr } & 1 & $0.5 \mathrm{lb}$ ae & $0.1 \%$ Sylgard & $58 \mathrm{e}$ \\
\hline & 2 & $0.5 \mathrm{lb}$ ae & $0.1 \%$ Sylgard & $84 a b c$ \\
\hline
\end{tabular}

"Means for percent control followed by the same letter are not significantly different at $5 \%$ level.

TABLE 2. Chemical control of yellow starthistle seedlings in Central Valley grasslands (Davis) with treatment timings between November 1996 and April 1997

\begin{tabular}{|c|c|c|c|c|c|c|c|}
\hline \multirow[b]{2}{*}{ Herbicide } & \multirow{2}{*}{$\begin{array}{c}\text { Rate } \\
\text { per acre }\end{array}$} & \multicolumn{6}{|c|}{ Control* } \\
\hline & & Nov & Dec & Jan & Feb & Mar & Apr \\
\hline \multirow{7}{*}{ Clopyralid } & & & & & ............ & 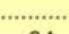 & ......... \\
\hline & $0.25 \mathrm{oz}$ ae & 55 & 45 & 68 & 63 & 64 & 55 \\
\hline & $0.5 \mathrm{oz}$ ae & 86 & 85 & 75 & 87 & 84 & 85 \\
\hline & $1.0 \mathrm{oz}$ ae & 91 & 93 & 98 & 100 & 97 & 100 \\
\hline & $2.0 \mathrm{oz}$ ae & 83 & 98 & 98 & 100 & 100 & 100 \\
\hline & $4.0 \mathrm{oz}$ ae & 93 & 100 & 98 & 100 & 100 & 100 \\
\hline & $6.0 \mathrm{oz}$ ae & 97 & 100 & 100 & 100 & 98 & 100 \\
\hline $\begin{array}{l}\text { Chlorsulfuron } \\
+2,4-D\end{array}$ & $2.0 \mathrm{oz} a \mathrm{a}+1,0 \mathrm{lb}$ ae & - & 95 & 69 & 90 & 90 & $\longrightarrow$ \\
\hline $\begin{array}{l}\text { Chlorsulfuron } \\
+ \text { triclopyr }\end{array}$ & $2.0 \mathrm{ozai}+0.75 \mathrm{lb}$ ae & $\longrightarrow$ & $\longrightarrow$ & - & 95 & 91 & $\longrightarrow$ \\
\hline $2,4-D$ & $1.0 \mathrm{lb}$ ae & $\longrightarrow$ & - & - & - & 90 & $\longrightarrow$ \\
\hline Triclopyr & $0.75 \mathrm{lb}$ ae & $\longrightarrow$ & - & - & $\longrightarrow$ & 58 & $\longrightarrow$ \\
\hline
\end{tabular}

-Least Significant Difference (5\%) for rates of clopyralid over all months was 11.0 . Overall LSD (5\%) was 40.9. Month of application effect on clopyralid was not significant. 
with earlier application timing (fig. 2a). Although not statistically significant, higher rates led to consistently less yellow starthistle compared with lower rates. However, this response did not appear to be due entirely to residual herbicide activity, as later application timings were not significantly different from early-season treatments. Early-season treatments also tended to increase desirable forage production compared with untreated plots and late-season treatments (fig. 2b). Furthermore, in some cases higher rates also increased desirable forage production compared with lower rates. The early-season treatment at higher labeled rates not only provides excellent control in the year of treatment, but may also give both increased yellow starthistle control and desirable spring forage biomass 1 year after application.

Although clopyralid can effectively control yellow starthistle from December through May, the optimum timing for treatment appears to be between January and March in most locations in California. This is particularly true if the primary object of a starthistle management program is to enhance forage quality and quantity in rangeland and grassland environments.

\section{Foliar and soil sensitivity}

We further compared the dose response of yellow starthistle seedlings under greenhouse conditions to several pre- and postemergence rates of clopyralid. Postemergence treatments were conducted with and without the addition of a surfactant. Ten to 20 seeds were planted in 4-inch pots. Preemergence treatments were made immediately after sowing using a compressed-air, table-spray chamber delivering 17.7 gallons per acre at 30 psi through an 8002E nozzle. After thinning to three to five seedlings per pot, postemergence applications were made to plants after two "true leaves" developed. Each treatment was replicated four times. Visual injury evaluations were used for relative comparisons between pre- and postemergence applications.

Our results indicate that the $\mathrm{VI}_{50}$ (rate which caused a level of visible injury of $50 \%$ relative to untreated seedlings) for pre- and postemergence $\left(\mathrm{VI}_{50}=0.140 \mathrm{oz}\right.$ ae/acre and $0.113 \mathrm{oz}$ ae/acre, respectively, without surfactant) applications were similar (fig. 3). This is supported by the wide timing window for control of starthistle seedlings under field conditions. Furthermore, the addition of an organosilicone surfactant ( $0.1 \%$ Sylgard) seemed to provide somewhat lower levels of yellow starthistle seedling control compared with treatments without surfactant. Two to three times more herbicide $\left(\mathrm{VI}_{50}=0.342 \mathrm{oz}\right.$ ae$/$ acre $)$ was required for the same level of injury when an organosilicone surfactant was added.

\section{Late-season starthistle control}

We conducted experiments in 1995 and 1997 to determine the most effective herbicide for late-season

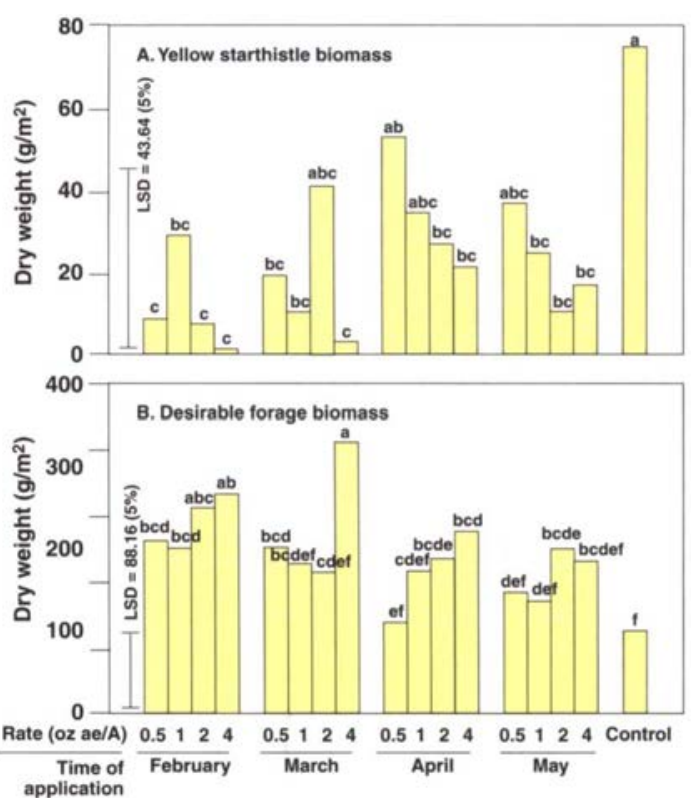

Fig. 2. Effect of clopyralid rate and timing on spring (A) biomass of yellow starthistle and (B) desirable forage in Siskiyou County, 1998. Desirable forage consisted of annual and perennial grasses, and forbs other than yellow starthistle.

control of yellow starthistle. Several rates of glyphosate, triclopyr, clopyralid, 2,4-D and dicamba were applied to starthistle in the following late rosette stages: just prior to bolting (1997 only), bolting, spiny (bud) and early flowering ( $2 \%$ to $5 \%$ flower). Plants were treated as previously described with a minimum of 10 replicates (individual plants) per treatment in 1995 and four replicates (plots consisting of six plants each) per treatment in 1997. All treatments, except glyphosate, were applied with the addition of $0.1 \%$ Sylgard as a surfactant. Because late-season control typically

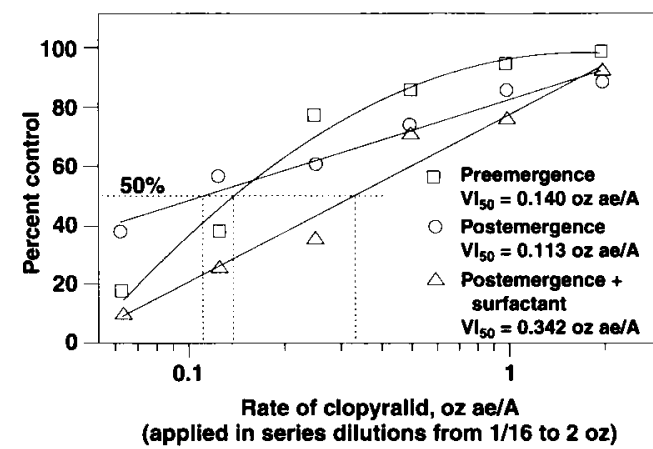

Fig. 3. Effect of application technique on clopyralid control of greenhouse-grown yellow starthistle seedlings. $\mathrm{VI}_{50}=$ rate which caused $50 \%$ visible injury to seedlings in comparison to untreated plants. 
occurs during the warmer spring or early summer months, amine formulations of both 2,4-D and triclopyr were used.

In 1995, we compared two rates of glyphosate and triclopyr at three stages of yellow starthistle development. Glyphosate at both rates provided excellent control at all stages (table 4). In contrast, triclopyr provided only marginal control in the bolting stage and poor control at later growth stages. In 1997, control of laterosette plants was excellent with all herbicides tested except for the lowest rate of glyphosate or triclopyr (table 5). Glyphosate, dicamba, and higher rates of clopyralid and triclopyr continued to be effective when plants were in the bolting stage. At the spiny and early flowering stages, yellow starthistle plants were noticeably drought-stressed. Control was poor for all herbicides tested, regardless of the application rate. Differences between the results for glyphosate in 1995 and 1997 could be attributed to the lack of spring rainfall in 1997, compared with 1995.

If late-season yellow starthistle control is necessary, the best time to treat with glyphosate is after annual grasses or broadleaf species have completed their life cycle, but prior to yellow starthistle seed production ( $<5 \%$ flowering). Control is less effective when mature plants show physical signs of drought-stress. When clopyralid was previously applied in late winter or early spring, glyphosate can be used in a broadcast or spot treatment followup program to kill uncontrolled plants before they produce seed. It can also be used to prevent the proliferation of potential clopyralid-resistant plants. Broadcast treatment with glyphosate is not recommended when desirable perennial grasses or broadleaf species are present.

\section{Advantages and warnings}

There are several advantages to using clopyralid for yellow starthistle control over other postemergence herbicides registered for use in rangeland, pastures and wildland areas. It has both pre- and postemergence activity at very low use rates, a low toxicology profile and no grazing restrictions. Treatments in December or later gave season-long control of starthistle, with earlier applications resulting in greater
TABLE 4. Late-season control of yellow starthistle with glyphosate and triclopyr in 1995. Plants treated in bolting, spiny, and early flowering ( $<5 \%$ bloom) stages

\begin{tabular}{|c|c|c|c|c|}
\hline \multirow[b]{2}{*}{ Herbicide } & \multirow[b]{2}{*}{ Rate } & \multicolumn{3}{|c|}{ Control } \\
\hline & & Bolting & Spiny & Early flowering \\
\hline & Ib ae/acre & ................ & $\ldots . \% \ldots$ & ............................ \\
\hline \multirow[t]{2}{*}{ Glyphosate } & 1.0 & $100 \mathrm{a}^{*}$ & $100 \mathrm{a}$ & $100 \mathrm{a}$ \\
\hline & 2.0 & $100 \mathrm{a}$ & $100 \mathrm{a}$ & $100 \mathrm{a}$ \\
\hline \multirow[t]{2}{*}{ Triclopyr } & 0.75 & 77 b & $46 \mathrm{c}$ & $24 c$ \\
\hline & 1.5 & $87 b$ & $71 \mathrm{~b}$ & $54 \mathrm{~b}$ \\
\hline
\end{tabular}

-For each trial, means followed by the same letter within a column are not significantly different at $5 \%$ level.

TABLE 5. Late-season chemical control of yellow starthistle in 1997. Plants in late-rosette, bolting, spiny, and early flowering $(<5 \%$ bloom) stages

\begin{tabular}{|c|c|c|c|c|c|c|}
\hline \multirow[b]{2}{*}{ Herbicide } & \multirow[b]{2}{*}{ Rate } & \multicolumn{4}{|c|}{ Control } & \multirow{2}{*}{$\begin{array}{r}\text { LSD } \\
(0.05)\end{array}$} \\
\hline & & Late rosette & Bolting & Spiny & Early flowering & \\
\hline & roz ae/acre & & &..$\%$.. & ................. & \\
\hline \multirow[t]{3}{*}{ Glyphosate } & $0.5 \mathrm{lb}$ & 73 & 88 & 38 & 32 & 29 \\
\hline & $1.0 \mathrm{lb}$ & 100 & 100 & 65 & 32 & 18 \\
\hline & $2.0 \mathrm{lb}$ & 100 & 100 & 73 & 60 & 26 \\
\hline \multirow[t]{2}{*}{ Triclopyr } & $0.75 \mathrm{lb}$ & 93 & 67 & 30 & 30 & 8 \\
\hline & $1.5 \mathrm{lb}$ & 100 & 95 & 37 & 15 & 22 \\
\hline \multirow[t]{2}{*}{$2,4-D$} & $1.0 \mathrm{lb}$ & 100 & 85 & 53 & 35 & 11 \\
\hline & $2.0 \mathrm{lb}$ & 100 & 85 & 40 & 22 & 22 \\
\hline \multirow[t]{2}{*}{ Dicamba } & $0.5 \mathrm{lb}$ & 100 & 98 & 55 & 20 & 24 \\
\hline & $1.0 \mathrm{lb}$ & 100 & 100 & 40 & 27 & 17 \\
\hline \multirow[t]{4}{*}{ Clopyralid } & $1.0 \mathrm{oz}$ & 100 & 78 & 27 & 10 & 24 \\
\hline & $2.0 \mathrm{oz}$ & 100 & 92 & 37 & 25 & 23 \\
\hline & $4.0 \mathrm{oz}$ & 100 & 100 & 60 & 27 & 22 \\
\hline & $6.0 \mathrm{oz}$ & 100 & 100 & 70 & 37 & 20 \\
\hline LSD & - & 14 & 17 & 18 & 26 & - \\
\hline
\end{tabular}

desirable forage production in the year of treatment, as well as the following spring. Clopyralid, glyphosate and dicamba also give effective late-season control of yellow starthistle, provided applications are not made when plants are drought-stressed.

It is important to recognize the possibility that other undesirable species, particularly annual grasses such as medusahead (Taeniatherum caputmedusae [L.] Nevski) or barbed goatgrass (Aegilops triuncialis L.), may replace yellow starthistle in clopyralidtreated areas. Under these conditions, other management strategies may be necessary. In addition, continuous clopyralid use over many years may have a long-term detrimental effect on legume populations, and potentially soil nitrogen levels. Consequently, other control options should be rotated in the overall yellow starthistle management program. Also, the potential exists for the evolution of resistance to clopyralid if the herbicide is used year after year without employing other methods. The potential for resistance can be minimized by using other strategies or through late-season applications of glyphosate to control escapes.

J.M. DiTomaso is Non-Crop Extension Weed Ecologist, G.B. Kyser is Staff Research Associate, and S.F. Enloe is Graduate Student, Department of Vegetable Crops, UC Davis; S.B. Orloff is Farm Advisor, Siskiyou County; and G.A. Nader is Farm Advisor, Sutter-Yuba-Butte Counties.

This project was partially funded by Dow AgroScience.

\section{Further reading}

Carrithers VF. 1998. Transline herbicide in rangeland and wildlife habitat restoration Proceedings, Calif. Weed Sci Soc. 50:138-41.

DiTomaso JM, Lanini WT, Thomsen CD, Prather TS, et al. 1999. Pest Notes: Yellow starthistle. UC Division of $\mathrm{Ag}$ and $\mathrm{Nat} \mathrm{Re}-$ sources, No. 7402.4 p.

DiTomaso JM, Orloff SB, Kyser GB and Nader GA. 1998. Influence of timing and chemical control on yellow starthistle. Proceedings, Calif. Weed Sci Soc. 50:190-3.

Lass LW and Callihan RH. 1994. Herbicide evaluation for yellow starthistle control. Res Prog Rept. Westem Soc Weed Sci. p 1-42.

Northam FE and Callihan RH. 1991. Effects of herbicides on yellow starthistle density and vegetative biomass. Res Prog Rept. Western Soc Weed Sci. p 43-6. 